\title{
PRESUPPOSITION IN KIM NAMJOON'S SPEECH AT UNITED NATION GENERAL ASSEMBLY
}

\author{
Sayyidah Aminah ${ }^{1}$ \\ ${ }^{1}$ IKIP Siliwangi \\ ${ }^{1}$ sayyidahaminah@student.ikipsiliwangi.ac.id
}

\begin{abstract}
This research entitled "Presupposition in Kim Nam Joon's Speech at United Nation General Assembly. It is a descriptive analysis of speech that used types of presuppositions". The objectives of this research are to know the types of presupposition and to find out the most dominant type of presupposition in the speech of Kim Namjun. The research method used qualitative descriptive and it is used to analyse the speech as a sample based on Guswita \& Widodo's theory. They mention that six types of presupposition, there are; existential presupposition, factive presupposition, lexical presupposition, structural presupposition, non-factive presupposition, and counterfactual presupposition. In analyzing, the research watched the speech which lasts about six minutes, then transcribed, and analysed based on Guswita \& Widodo's theory (2019). The result of this study shows that there are four types of presupposition in the speech; existential presuppositions, lexical presupposition, non-factive presupposition, and structural presupposition. With the percentage of existential is 20 or $62.05 \%$, lexical are 9 or $28,12 \%$, structural are 2 or $6.25 \%$, and the last non-factive is just 1 or 3,12\%. So, the most dominant type is commonly used in the Kim Namjun's Speech at UNs General Assembly is existential presuppositions.
\end{abstract}

Keywords: Presupposition, UN' General Assembly, Kim Namjoon's Speech

\section{INTRODUCTION}

Pragmatic is one of material that learned in linguistic. Human learning linguistic to know whatever is in an utterance and the meaning that are in utterance. Pragmatic analysis of functional Linguistics part of having external elements of language comprehensive (Harmani $\&$ Puluhulawa, 2019). Pragmatics cling to external elements that determine the meaning of the speech is the speaker in communicating. According to Sintamutiani, Fitriani, \& Inayah (2019), Pragmatics is the study of meanings that are delivered by the speaker or writer and defined through the listener or reader. In pragmatic there are some materials that must be learned, such as: deixis and distance, reference and inference, presupposition, cooperative principle, implicature, speech act, e.t.c. And in this research, researcher focuses on presupposition. Presupposition can defined as speaker assumes. Risdianto, Malihah, \& Guritno (2019) state presupposition is a thing that is presupposed, while presupposes means to assume something true before it is proved. Presupposition can occur in verbal and written language, in daily conversation or in the use of conversation. In other words, presupposition is the study of how the speaker can assume something in an utterance. Presupposition is something that is assumed by the speaker as his case before delivering a speech. The speaker, not the sentences, have a presumption (Tambunan, Lubis, Purba, Girsang, \& Sembiring, 2019). For example someone said "Why did you arrive late?" it means: You are late. Presuppositions are unsaid beliefs; these helps provide meaning to what a person says or refers to (Haji \& Mohammed, 2019). In producing statement, the speaker is generally be assumed that "you" are late, so the speaker ask to "you" that. 
There are categories of presupposition triggers; existential presupposition, factive presupposition, lexical presupposition, non-factive presupposition, counter-factual presupposition and structural presupposition (Gençtürk, 2018; Yule, 2006). they define each category as follows: 1) Existential presupposition is the possessive construction in English and any definite noun phrase can be associated with existential presupposition. E.g. the King of Sweden (There is a king in Sweden.), 2) Factive is the assumption that something is true due to the presence of some verbs such as 'know', 'realize', 'regret', etc. E.g. Daniel did not realize Dinda is gone. (Dinda is gone.) E.g. Noah regret eating junkfood. (Noah ate junkfood.), 3) Lexical is that in using one word, the speaker can act as if another non-asserted meaning (word) will be understood. E.g. He stopped smoking. (He used to smoke.), 4) Non-factive is an assumption referrred to something that is not true. Verbs like 'dream', 'imagine' and 'pretend' are generally used. E.g. I dreamed that I was rich. (I was not rich.), 5) Counter-factual, in this trigger, what is presupposed is not only untrue, but is the contrary of what is true or contradictory facts. E.g. If you were my friend, you would went with me. (You are not my friend.), 6) Structural. In this type, the listener percieves that the information presented is necessarily true, or intented as true by the speaker. E.g. When did he leave? (He left).

This research focuses on presupposition in Kim Namjun's speech at United Nation general assembly. Kim Namjun is one of member of BTS. They had the opportunity to give a speech at the UN General Meeting, on Monday, September 24, 2018 in New York, America. On this occasion the BTS - represented by the leader-Kim Namjun, delivered a speech entitled "love yourself" same as one of their campaign albums. Kim Namjun gave a six-minute speech and clarified that BTS and UNICEF did indeed work together to stop violence against children and invite the wider community to voice their "love yourself" campaign.

Based on previous study, researcher wants to analyze presupposition with Kim Namjun's speech at UN's general meeting as a sample. With the presupposition triggers, the researcher identifies the utterance that not said in the speech, and how to analyze the utterance unsaid in the speech using presupposition triggers, and to know which one the dominant type of presupposition.

\section{METHOD}

The sample of this research is the transcript of Kim Namjun's speech on monday, September 24, 2018. This study used qualitative descriptive method. According to Lugina, Nuryulia, \& Suprijadi (2019) Qualitative data are collected in the form of words or images, not numbers. This means that this research is based on the characteristics of the phenomenon and the data were analyzed using descriptions instead of numbers. The data analysis of this research is based on theory of Guswita \& Widodo (2019), in which the presupposition through from the presupposition triggers. The first step the writer will watch the video of Kim Namjun's speech which is arround 6:30 minutes, then make the transcript of the speech. Second, identifying the words that related to presupposition triggers, and then collecting with the types of triggers. Last, list the sentence on the table.

\section{RESULTS AND DISCUSSION}

\section{Results}


Based on the finding, there are four types of presupposition in Kim Namjun's speech. First one is existential presupposition with 20 sentences, lexical presupposition with nine sentences, structural presupposition with two sentences, and the last one is non-factual presupposition with one sentence. This is the result of research with calculations using the formula above:

Existential $=20 \div 32 * 100=62.5 \%$

Lexical $=9 \div 32 * 100=28.125 \%$

Structural $=2 \div 32 * 100=6.25 \%$

Non-Factive $=1 \div 32 * 100=3.125 \%$

Picture 1 : Diagram of the data

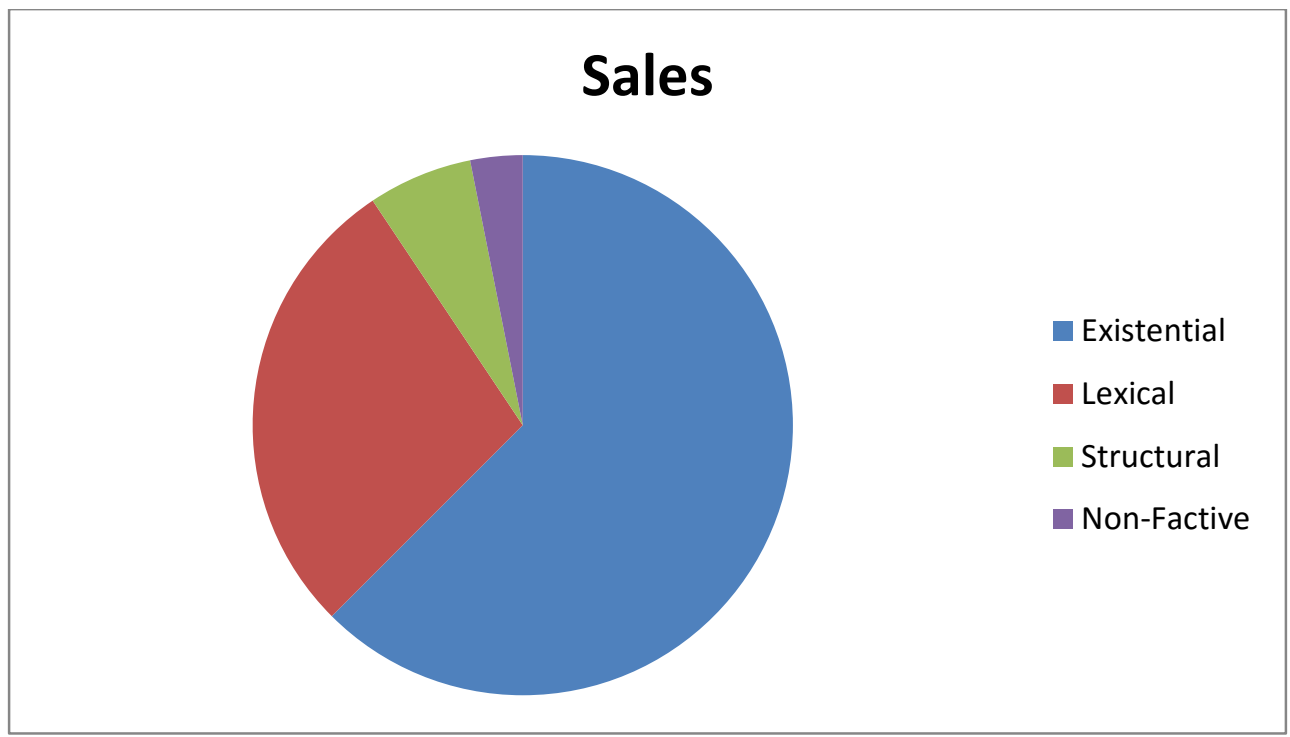

\section{Discussion}

As the calculation of the occurrences, it was found that dominant type presupposition used in the Kim Namjun's speech at UNs General Meeting was existential presupposition (62,5\%), then lexical presupposition $(28,12 \%)$, non-factive $(3,12 \%)$, and structural presupposition $(6.25 \%)$

Table 1: Research Data in Kim Namjun's Speech

\section{A. Existential Presupposition}

\begin{tabular}{|c|c|c|}
\hline No. & Time & Explanation \\
\hline 1 & $0: 11$ & $\begin{array}{l}\mathrm{P}=\text { My name is Kim Namjun } \\
\mathrm{Q}=\text { There is a person named Kim Namjun }\end{array}$ \\
\hline 2 & $0: 14$ & $\begin{array}{l}\mathrm{P}=\mathrm{RM} \text { the leader of the group BTS } \\
\mathrm{Q}=\text { There is a person named RM } \\
\text { There is a group named BTS } \\
\text { BTS has a leader }\end{array}$ \\
\hline 3 & $0: 33$ & $\begin{array}{l}\mathrm{P}=\mathrm{We} \text { have been partnering with UNICEF's \#ENDViolence program } \\
\mathrm{Q}=\mathrm{UNICEF} \text { has a program }\end{array}$ \\
\hline
\end{tabular}




\begin{tabular}{|c|c|c|}
\hline 4 & $0: 37$ & $\begin{array}{l}\mathrm{P}=\text { To protect children and young people all over the world from violence } \\
\mathrm{Q}=\text { There is a children } \\
\text { There is a young people } \\
\text { There is a violence in the world }\end{array}$ \\
\hline 5 & $0: 42$ & $\begin{array}{l}\mathrm{P}=\text { Our fans have become a major part of this campaign } \\
\mathrm{Q}=\text { There is a fans } \\
\text { There is a campaign }\end{array}$ \\
\hline 6 & $0: 48$ & $\begin{array}{l}\mathrm{P}=\text { We truly have the best fans in the world } \\
\mathrm{Q}=\text { There is a fans in the world }\end{array}$ \\
\hline 7 & $0: 57$ & $\begin{array}{l}\mathrm{P}=\text { Born in Ilsan, a city near Seoul } \\
\mathrm{Q}=\text { Ilsan city is exist } \\
\quad \text { Seoul is exist }\end{array}$ \\
\hline 8 & $1: 02$ & $\begin{array}{l}\mathrm{P}=\mathrm{It} \text { is really beautiful place with a lake } \\
\mathrm{Q}=\text { There is a place with a lake }\end{array}$ \\
\hline 9 & $1: 11$ & $\begin{array}{l}\mathrm{P}=\mathrm{I} \text { was just an ordinary boy } \\
\mathrm{Q}=\text { Ordinary boy is exist }\end{array}$ \\
\hline 10 & 2:02 & $\begin{array}{l}\mathrm{P}=\text { Shut out my own voice } \\
\mathrm{Q}=\text { He has his own voice }\end{array}$ \\
\hline 11 & $2: 10$ & $\begin{array}{l}\mathrm{P}=\text { Called out my name } \\
\mathrm{Q}=\text { He has a name }\end{array}$ \\
\hline 12 & $2: 16$ & $\begin{array}{l}\mathrm{P}=\text { My eyes closed } \\
\mathrm{Q}=\text { He had an eyes }\end{array}$ \\
\hline 13 & $2: 30$ & $\begin{array}{l}\mathrm{P}=\mathrm{I} \text { had one sanctuary } \\
\mathrm{Q}=\text { There is a sanctuary }\end{array}$ \\
\hline 14 & $2: 36$ & $\begin{array}{l}\mathrm{P}=\text { There was a small voice inside of me } \\
\mathrm{Q}=\text { There is a small voice }\end{array}$ \\
\hline 15 & $2: 43$ & $\begin{array}{l}\mathrm{P}=\text { calling my real name } \\
\mathrm{Q}=\text { He has a real name }\end{array}$ \\
\hline 16 & $3: 15$ & $\begin{array}{l}\mathrm{P}=\mathrm{BTS} \text { has become artist } \\
\mathrm{Q}=\mathrm{BTS} \text { is exist } \\
\text { There is an artist }\end{array}$ \\
\hline 17 & $3: 17$ & $\begin{array}{l}\mathrm{P}=\text { Performing in the huge stadiums } \\
\mathrm{Q}=\text { There is a huge stadiums }\end{array}$ \\
\hline 18 & $3: 19$ & $\begin{array}{l}\mathrm{P}=\text { Selling millions of albums } \\
\mathrm{Q}=\text { There is an albums }\end{array}$ \\
\hline 19 & $3: 52$ & $\begin{array}{l}\mathrm{P}=\text { With all my faults and my mistakes } \\
\mathrm{Q}=\text { He has a faults and mistakes }\end{array}$ \\
\hline 20 & $5: 44$ & $\begin{array}{l}\mathrm{P}=\mathrm{I} ' \mathrm{~m} \text { an idol and I'm an artist from a small town in Korea } \\
\mathrm{Q}=\text { There is an idol } \\
\text { There is an artist } \\
\text { There is a small town in Korea }\end{array}$ \\
\hline
\end{tabular}

\section{B. Lexical Presupposition}

\begin{tabular}{lll}
\hline No. & Time & Explanation \\
$\mathbf{1}$ & $0: 53$ & $\begin{array}{l}\mathrm{P}=\text { I'd like to begin by talking about myself } \\
\mathrm{Q}=\text { He was not talking about himself }\end{array}$ \\
$\mathbf{2}$ & $1: 43$ & $\begin{array}{l}\mathrm{P}=\mathrm{I} \text { started seeing myself through their eyes } \\
\mathrm{Q}=\text { He was not seeing himself }\end{array}$
\end{tabular}




\begin{tabular}{|c|c|c|}
\hline 3 & $1: 47$ & $\begin{array}{l}\mathrm{P}=\mathrm{I} \text { stopped looking up at the night } \\
\mathrm{Q}=\text { He was looking up at the night }\end{array}$ \\
\hline 4 & $1: 51$ & $\begin{array}{l}\mathrm{P}=\mathrm{I} \text { stopped daydreaming } \\
\mathrm{Q}=\text { He was daydreaming }\end{array}$ \\
\hline 5 & $2: 01$ & $\begin{array}{l}\mathrm{P}=\mathrm{I} \text { began to shut out my own voice } \\
\mathrm{Q}=\text { He was not shut out his own voice }\end{array}$ \\
\hline 6 & $2: 05$ & $\begin{array}{l}\mathrm{P}=\mathrm{I} \text { started to listen the voice of others } \\
\mathrm{Q}=\text { He was not listen other's voice }\end{array}$ \\
\hline 7 & $3: 22$ & $\begin{array}{l}\mathrm{P}=\mathrm{I} \text { 'm still an ordinary } 24 \text {-year-old guy } \\
\mathrm{Q}=\text { He was an ordinary guy }\end{array}$ \\
\hline 8 & $4: 34$ & $\begin{array}{l}\mathrm{P}=\mathrm{We} \text { started to hear remarkable stories } \\
\mathrm{Q}=\mathrm{We} \text { were not hear remarkable stories }\end{array}$ \\
\hline 9 & $4: 42$ & $\begin{array}{l}\mathrm{P}=\text { they start loving themselves } \\
\mathrm{Q}=\text { They were not love themselves }\end{array}$ \\
\hline
\end{tabular}

\section{Structural Presupposition}

\begin{tabular}{lll}
\hline No. & Time & Explanation \\
$\mathbf{1}$ & $0: 58$ & $\begin{array}{l}\mathrm{P}=\mathrm{I} \text { was born in Ilsan } \\
\mathrm{Q}=\text { Someone has born in Ilsan }\end{array}$ \\
$\mathbf{2}$ & $1: 07$ & $\begin{array}{l}\mathrm{P}=\mathrm{I} \text { spend a very happy childhood } \\
\mathrm{Q}=\text { Someone has very happy childhood }\end{array}$ \\
\hline
\end{tabular}

\section{Non-Factive Presupposition}

\begin{tabular}{lll}
\hline No. & Time & Explanation \\
$\mathbf{1}$ & $1: 22$ & $\mathrm{P}=\mathrm{I}$ used to imagine that I was a superhero \\
& & $\mathrm{Q}=\mathrm{He}$ is not a superhero \\
\hline
\end{tabular}

Based on the table, the researcher found four types of presupposition there are; 1) Exictential, 2) Lexical, 3) Structural, and 4) Non-Factive. The dominant type is existential with 20 sentence or $62.05 \%$, and the last one is non-factive with one word or $3.12 \%$. Meanwhile in other study, Sukmawati \& Wijayanto (2020), showed that existential presuppositions, 31 (26.3\%) factive presuppositions, $11(9.3 \%)$ lexical presuppositions, 17 (14.4\%) structural presuppositions, 2 (1.7\%) non-factive presuppositions, and $2(1.7 \%)$ counterfactual presuppositions, it means in that study there are six types of presupposition was detected. In addition, Janam (2019), in his research's title A Textual Analysis of Presupposition and Grice's Maxims in Clinton's Testimony and His Speech After The Trial, showed that the most dominant types are existential presupposition and factive presupposition.

\section{CONCLUSION}

The Presupposition in the Kim Namjun's Speech at UNs General Assembly has been analyzed. It can be concluded that just 4 types of presuppositions are exist in that script: existential presuppositions, lexical presupposition, non-factive presupposition, and structural presupposition. The numbers of whole presuppositions found are 32. Percentages type of presupposition in the Kim Namjun's Speech: the percentage of existential presupposition is 20 
or $62.05 \%$, lexical presupposition are 9 or $28.12 \%$, structural presupposition are 2 or $6.25 \%$, and the last non-factive presupposition is just 1 or $3.12 \%$. So, the dominant type is commonly used in the Kim Namjun's Speech at UNs General Assembly is existential presuppositions.

\section{ACKNOWLEDGMENTS}

First the author want to thank to Allah SWT, because he the author get the power to finished this research very well. To author's parents of course, who was support the author and gave the money for needed in college. To author's lecture Mrs. Lilis Suryani, M.Pd. who always have given direction to completed this research. The last thank you for IKIP Siliwangi author's beloved campus.

\section{REFERENCES}

Gençtürk, S. (2018). Analysis of Presupposition Triggers in English Reading Textbooks: Learners' Familiarity. Uluslararası Bilim ve Eğitim Dergisi, 1(1).

Guswita, K. A., \& Widodo, P. (2019). Presupposition Triggers in the Washington Post and Lost Angeles Times Online News. LINGUA: Journal of Language, Literature and Teaching, 16(1). Retrieved from https://doi.org/10.30957/lingua.v16i1.572

Haji, S. S., \& Mohammed, F. O. (2019). The Use of Presuppositions in the Short Story of Zilkê Şixatê (Matchstick). UKH Journal of Social Sciences, 3(2). https://doi.org/10.25079/ukhjss.v3n2y2019

Harmani, T., \& Puluhulawa, Y. (2019). Pragmatics Analysis of Maxim Flouting Done by the Main Characters in Kungfu Panda Movie by Jonathan Aibel \& Glenn Berger. British: Journal Bahasa Dan Sastra Inggris, 8(1). Retrieved from http://journal.umgo.ac.id/index.php/British/article/view/331

Janam, I. J. (2019). A Textual Analysis of Presupposition and Grice's Maxims in Clinton's Testimony and His Speech After The Trial. Transylvanian Review. Retrieved from http://www.transylvanianreviewjournal.org/index.php/TR/article/view/3844

Lugina, G., Nuryulia, E., \& Suprijadi, D. (2019). Deixis in the Legend of Lake Toba Story. PROJECT (Professional Journal of English Education), 2(5).

Risdianto, F., Malihah, N., \& Guritno, A. (2019). The Analysis of Presupposition in George Orwell's Novella Animal Farm. Journal of Pragmatics Research, 1(1), 1-12.

Sintamutiani, D. P., Fitriani, D., \& Inayah, R. (2019). an Analysis of Speech Act Classification in Beauty and the Beast. PROJECT (Professional Journal of English Education), 2(4), 429. https://doi.org/10.22460/project.v2i4.p429-435

Sukmawati, S., \& Wijayanto, A. (2020). Analysis of Verbal Humor in Friends from a Perspective of Pragmatic Presupposition. Electronic Theses and Dissertations. Retrieved from http://eprints.ums.ac.id/80096/

Tambunan, A. R. S., Lubis, F. K., Purba, N., Girsang, M., \& Sembiring, E. M. B. (2019). Presupposition in "Barbie and the Magic of Pegasus" Movie. Asian Themes in Social Sciences Research, 3(1), 18-21. https://doi.org/10.33094/journal.139.2019.31.18.21

Yule. (2006). Pragmatics. Oxford: Oxford University Press. 